\title{
Somatostatin receptors and disease: role of receptor subtypes
}

\author{
LEO J. HOFLAND \\ STEVEN W. J. LAMBERTS
}

The small cyclic peptide somatostatin (SST) is present in the human body in two molecular forms, SS14 and SS28, consisting of 14 and 28 amino acids, respectively (Brazeau et al, 1973; Pradayrol et al, 1980). SST has widespread biological actions in different organ systems. Hypothalamic SST inhibits pituitary growth hormone and thyroid-stimulating hormone (TSH) release (as a neurohormone) and in the brain SST acts as a neurotransmitter having both stimulatory and inhibitory actions (Renaud et al, 1975; Dodd and Kelly, 1978). Next to these actions, locally produced SST may play a regulatory role in an autocrine and/or paracrine fashion in the endocrine and exocrine pancreas and in the gastrointestinal tract (Guillemin and Gerich, 1976). SST is also synthesized by lymphoid cells and may have an immunomodulatory role in these cell types (van Hagen et al, 1994).

Along with this variety of actions of SST, somatostatin receptors (SSTR) have been detected in most of the target organs of the peptide. By autoradiographic and membrane-homogenate binding studies, SSTR have been found in the central nervous system, the anterior pituitary gland, the endocrine and exocrine pancreas, the gastrointestinal tract and in (activated) immune cells in lymphoid tissues (Lamberts et al, 1991; van Hagen et al, 1994).

The presence of SSTR in this variety of organ systems suggested that SST could have a role in the treatment of disease due to hyperfunction of these systems. However, several disadvantages of the native peptide hampered its practical use (Guillemin, 1978; Lamberts, 1988). Due to its very short half-life in the circulation (less than 3 minutes) the peptide has a short duration of action and must therefore be infused intravenously. Moreover, the post-infusion rebound hypersecretion of hormones by normal tissues is a major disadvantage (Besser et al, 1974a,b). The search for analogues of SST not having these disadvantages has led to the development of a class of octapeptide SST-analogues with a prolonged biological half-life. Octreotide is currently the most widely used SST-analogue. It has a halflife in the circulation of approximately 2 hours, can be given subcutaneously and in monkeys is 45 times more potent in inhibiting GH release, 11 times more potent in inhibiting glucagon release and only 1.3 times 
more potent in inhibiting insulin release as compared to native SST (Bauer et al, 1982). Octreotide has proven to be a potent therapeutical agent for the treatment of acromegaly, and for certain tumours with amine precursor uptake and decarboxylation (APUD) characteristics (i.e. carcinoids and glucagonomas) (Lamberts, 1988; Schally, 1988; Lamberts et al, 1991). Two other octapeptide SST-analogues that have been developed for clinical use are BIM-23014 (somatuline; Heiman et al, 1987; Parmar et al, 1989) and RC-160 (octastatin; Cai et al, 1986, 1987). Both analogues are currently being tested in clinical trials.

\section{SOMATOSTATIN RECEPTOR SUBTYPES}

On the basis of a differential displacement of radiolabelled SST by unlabelled SST, and by several structural analogues of SST in homogenate membrane-binding studies and in in vitro receptor-autoradiographic studies, evidence has been provided for the existence of at least two SSTR proteins in the brain: one with a high affinity and one with a low affinity for octapeptide analogues (Reubi, 1984, 1985; Maurer and Reubi, 1985; Tran et al, 1985; Reubi et al, 1987). Cross-linking is a biochemical technique in which radiolabelled SST(-analogues) are covalently coupled to receptor proteins, followed by chromatography or polyacrylamide gel electrophoresis and subsequent autoradiography. By using this technique SSTR proteins with a molecular mass varying between 27 and $228 \mathrm{kDa}$ have been found in a variety of normal tissues (Rens-Domomiano and Reisine, 1992) and in human tumours (Prévost et al, 1992, 1993).

Altogether, these observations suggested the existence of SSTR subtypes. This has recently been confirmed by the cloning of five distinct human SSTR subtypes, called SSTR1, SSTR2, SSTR3, SSTR4 and SSTR5 (Yamada et al, 1992a,b, 1993a; Rohrer et al, 1993; Xu et al, 1993). These subtypes belong to the superfamily of G-protein-coupled receptors with seven transmembrane-spanning domains. In humans, the genes encoding for the SSTR subtypes have a distinct chromosomal localization and tissuespecific expression suggesting a differential function in different organ systems (Table 1). The SSTR subtypes have an amino acid identity ranging from 42 to 60\% (Yamada et al, 1993a). Differences have been found between the affinity of native SST and structural analogues of SST for the different SSTR subtypes. SS14 and SS28 bind with high affinity to all five subtypes, whereas the clinically applicable SST-analogues octreotide, RC160 and BIM-23014 bind with high affinity to the SSTR2 and SSTR5 subtypes only (Hoyer et al, 1994; Patel and Srikant, 1994; Table 2). These analogues bind with a relatively low affinity to the SSTR3 subtype and have no, or very low, affinity for the SSTR1 and SSTR 4 subtypes (Table 2 ). In line with these different pharmacological profiles, the highest homologies have been found within the transmembrane-spanning regions between the SSTR2, SSTR3 and SSTR5 subtypes on the one hand and between the SSTR1 and SSTR4 subtypes on the other hand (Hoyer et al, 1994). 

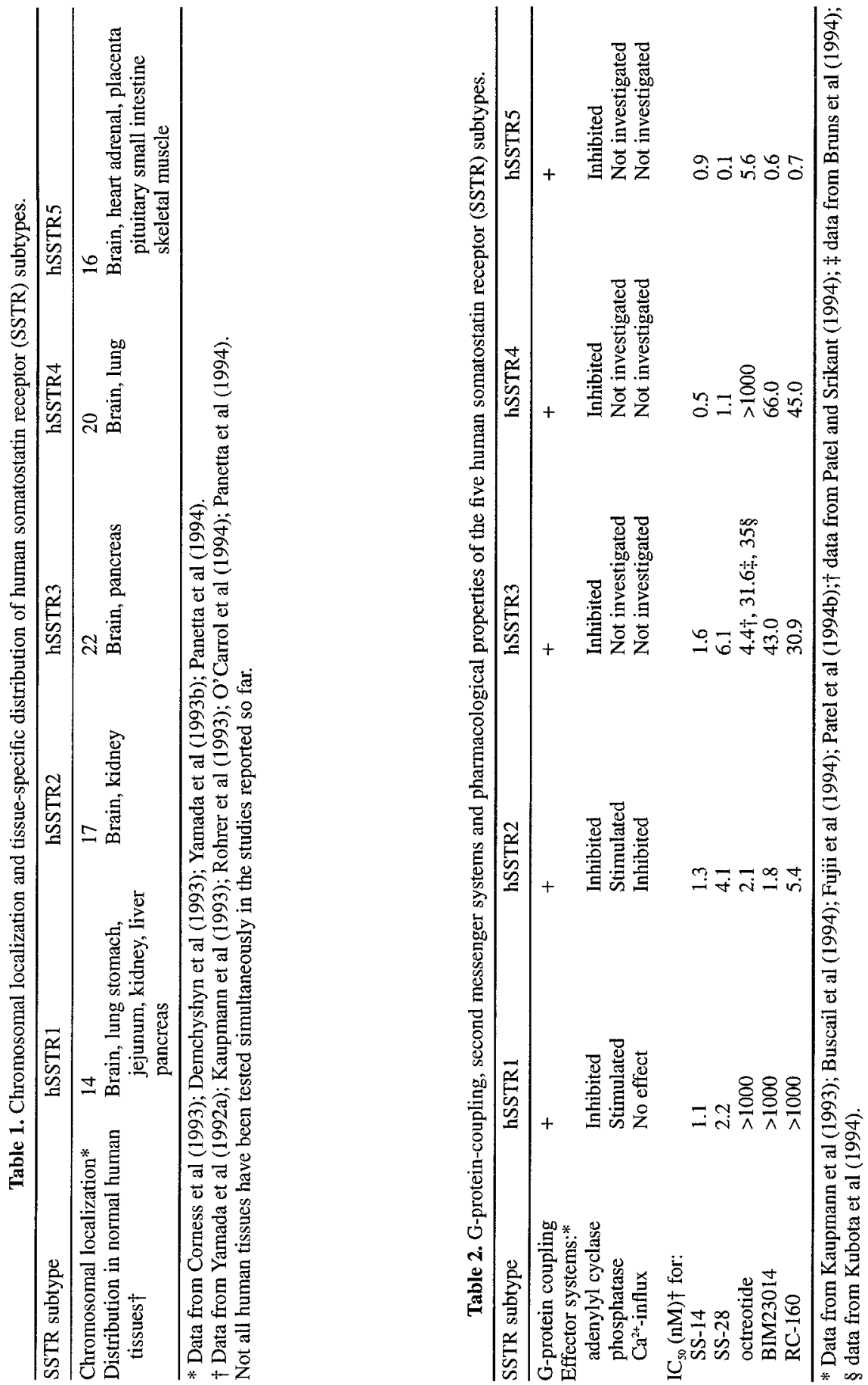
Different G-protein-coupled signal transduction systems can be activated after binding of SST to its receptor. SSTR activation may result, depending upon the cell type, in inhibition of adenylyl cyclase activity, thereby lowering intracellular cyclic adenosine monophosphate (cAMP) levels. Moreover, SSTR activation results in inhibition of $\mathrm{Ca}^{2+}$-influx via a direct interaction $\left(\mathrm{Ca}^{2+}\right.$-channels) or indirect interaction (stimulation of $\mathrm{K}^{+}$channels) with ion-channels (Patel et al, 1990). SSTR activation may also be linked via a G-protein-dependent mechanism to stimulation of a phosphotyrosine phosphatase. This latter effect is suggested to be associated with anti-proliferative actions of SST (Liebow et al, 1989). The five cloned SSTR subtypes have been shown to be linked to inhibition of adenylyl cyclase activity (Kaupmann et al, 1993; Patel et al, 1994b), while inhibition of $\mathrm{Ca}^{2+}$-influx through high voltage activated $\mathrm{Ca}^{2+}$-channels may be mediated via the SSTR2 subtype (Fujii et al, 1994). SST and SSTanalogues (octreotide and RC-160) may also cause stimulation of tyrosine phosphatase activity in NIH 3T3 cells stably expressing SSTR1 or SSTR2 (Buscail et al, 1994). A summary of these second messenger systems coupled to the different SSTR subtypes is listed in Table 2. Finally, in certain brain areas SSTR activation may induce stimulation of phospholipase $\mathrm{C}$ and $\mathrm{Ca}^{2+}$-mobilization. All five human SSTR subtypes have been shown to be linked to this system with a rank order of potency of SSTR5 $>$ SSTR2 $>$ SSTR3 $>$ SSTR4 $>$ SSTR1 (Akbar et al, 1994; Tomura et al, 1994). Knowing that one SSTR subtype may be coupled to multiple effector systems makes it difficult to establish which subtype(s) is involved in the inhibition of secretory processes on the one hand and which is involved in antimitotic actions of SST(-analogues) on the other hand.

\section{EXPRESSION OF SOMATOSTATIN RECEPTORS (SUBTYPES) IN DISEASE}

Most neuroendocrine tumours, often originating from SST target tissues, have conserved expression of a high density of high-affinity SSTR (Reubi et al, 1992a,b). A high density of SSTR has been demonstrated in different types of pituitary adenomas (GH-adenomas, TSH-adenomas and clinically non-functioning adenomas), as well as in islet cell tumurs, phaeochromocytomas, paragangliomas, small cell lung cancers, medullary thyroid carcinomas and carcinoids. SSTR have also been demonstrated in subgroups of breast, brain, colon and lung tumours (Lamberts et al, 1991; Reubi et al, $1992 a, b)$. While the majority of these tumours carry SSTR with a high affinity for native SST as well as for octapeptide SST-analogues such as octreotide, small subgroups of tumours have been described with highaffinity binding sites for SST, but not for octreotide. Among these subgroups of tumours are certain insulinomas, carcinoids, medullary thyroid carcinomas, ovarian cancers and pituitary GH-adenomas (Reubi et al, 1992a,b). The recent cloning of the five human SSTR subtypes has provided tools to study the expression of SSTR subtype mRNA in human tumours. By the use of the reverse transcriptase polymerase chain reaction (RT-PCR) 
it has been found that insulinomas, gastrinomas, glucagonomas, carcinoids and pheochromocytomas express multiple SSTR subtypes (Kubota et al, 1994). In their study, Kubota et al found no SSTR5 subtype mRNA expression in these types of tumours. Reubi et al (1994b) recently studied SSTR1, SSTR2 and SSTR 3 mRNA expression in 55 human primary tumours by in situ hybridization. They found that all pituitary GH- and TSH-adenomas, meningiomas, neuroblastomas, breast tumours and small cell lung cancers expressed the SSTR2 subtype. SSTR1 and SSTR3 mRNA expression was found less frequently, but most regularly found in gastroenteropancreatic (GEP) tumours, medullary thyroid cancers and ovarian cancers (Reubi et al, 1994b). Because SSTR1 and SSTR3 have absent or low affinity for the SSTanalogue octreotide, respectively, this may explain the differential binding of native SST and of octreotide in the subgroups of tumours described above.

The different types of pituitary adenomas also express multiple SSTR subtypes. The SSTR2 subtype is expressed in the majority of human pituitary GH-adenomas and in about half of the non-functioning adenomas (Greenman and Melmed, 1994a,b). Prolactinomas and ACTH-secreting pituitary tumours seem not to express this SSTR subtype, as demonstrated by RNAse protection assays and RT-PCR (Greenman and Melmed, 1994a,b). The SSTR5 subtype, which also binds the somatostatin analogue octreotide with a relative high affinity, is also expressed in the majority of the pituitary adenomas, except for the clinically non-functioning adenomas. In contrast to these observations, however, Panetta and Patel (1995) recently demonstrated SSTR2 mRNA expression in four out of six prolactinomas and in one ACTH-secreting pituitary tumour by RT-PCR followed by Southern blotting, with at the same time variable expression of other SSTR subtypes as well. At present it is unclear what causes these equivocal data. Care should be taken with the interpretation of data obtained by RT-PCR analysis of human tumour samples since Reubi et al (1994a) have shown by SSTR-autoradiographic studies that veins surrounding human cancer tissue may also express a high density of SSTR, as may activated immune cells (van Hagen et al, 1994). Both vessels and immune cells may be present in tumours which might result in false-positive results.

In addition to human primary tumours, a variety of experimental tumours and tumour cell lines of lung, breast, prostate and gastrointestinal origin express SSTR2 mRNA (Eden and Taylor, 1993; Fujita et al, 1994; Prévost et al, 1994; Taylor et al, 1994). Experimental small cell lung carcinomas also express SSTR1, but not SSTR3 mRNA (Eden and Taylor, 1993; Prévost et al, 1994).

\section{FUNCTIONAL SIGNIFICANCE OF SOMATOSTATIN RECEPTORS IN DISEASE: APPLICATION OF SOMATOSTATIN ANALOGUES}

From the limited number of studies so far, it is clear that expression of SSTR2 is important in mediating the clinical effects of octreotide. Urinary 5-HIAA excretion in a patient with a metastatic carcinoid lacking SSTR2 
expression was not lowered by octreotide treatment, while octreotide treatment lowered plasma glucagon levels in a patient with a glucagonoma expressing the SSTR2 subtype (Kubota et al, 1994). Two acromegalic patients with pituitary GH-adenomas exclusively expressing the SSTR2 subtype responded to octreotide therapy, suggesting that the SSTR2 subtype mediates the anti-hormonal actions of octreotide in these tumours (Greenman and Melmed, 1994a). At present the functional role of the other SSTR subtypes on human tumours remains unclear, however. Moreover, is there an additional therapeutical application for other octapeptide analogues of SST, such as BIM-23014 and RC-160? In an in vitro study with human pituitary GH-adenomas, we have found that RC-160 is significantly more potent in inhibiting GH release compared with octreotide and BIM-23014 (Hofland et al, 1994). As shown in Table 2 there are only slight differences between the binding characteristics of the three SST-analogues. Therefore, the most likely explanation for the differences in the potency of inhibition of $\mathrm{GH}$ release between $\mathrm{RC}-160$ on the one hand and by octreotide and BIM-23014 on the other may be a different activation of post-receptor signalling systems. It should be emphasized, however, that in our study GH-adenomas with an absent response to octreotide were unresponsive to RC-160 as well (Hofland et al, 1994). We have further investigated this issue in cultures of non-functioning pituitary adenomas and of one insulinoma. Preliminary results show that non-functioning pituitary adenomas may respond differentially to SST, octreotide, RC-160 and BIM-23014. An example of this is shown in Figure 1. FSH release by cultured pituitary adenoma cells of a patient with a clinically non-functioning pituitary adenoma was significantly inhibited by the $\mathrm{D}_{2}$-receptor agonist CV205-502 and by native SST. However, neither octreotide, nor RC-160 or BIM-23014, significantly inhibited FSH release from the cells of this patient. Similar observations were made using human insulinoma cells (Figure 2). Whereas SS14 and SS28 significantly inhibited insulin release in vitro, both octreotide and RC-160 were ineffective. Janson et al (1994) recently showed that three patients with carcinoid tumours which showed no uptake in vivo of the radiolabelled SST-analogue ["11'In-DTPA-DPhe' ${ }^{1}$ octreotide did not respond to therapy with octreotide, RC-160 or BIM23014 , respectively. It seems reasonable, therefore, to assume that an absent clinical beneficial effect of octreotide also implies an absent response to therapy with the two other octapeptide SST-analogues. However, when 'octreotide-binding sites' are present on tumoural cells there may be differences in the biological effects between the analogues. Another important conclusion that can be drawn from these preliminary data is that SSTR subtypes, other than the SSTR2 and SSTR5 subtypes which have a high affinity for octreotide, may mediate anti-hormonal actions of SST. Thus, there may be a therapeutic place for newly developed SSTR subtype selective SST-analogues.

SST and SST-analogues with high affinity for the SSTR2 subtype exert anti-proliferative effects on breast, small cell lung cancer, colon, pancreatic and prostate tumour cell lines in vitro and in vivo (Schally, 1988; Lamberts et al, 1991). As indicated above, SSTR2 mRNA is predominantly expressed 


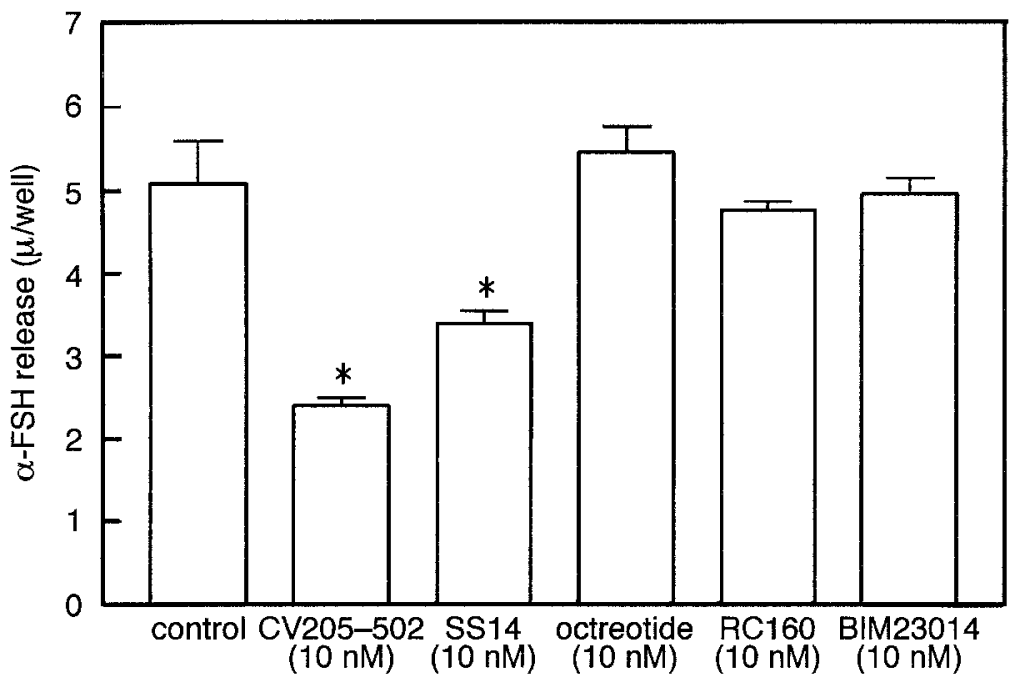

Figure 1. The effects of the $D_{2}$-receptor agonist CV 205-502, SS14 and SST-analogues on FSH release by cultured cells from a patient with a clinically non-functioning pituitary adenoma. The adenoma cells were cultured for 3 days in minimal essential medium with $10 \%$ FCS in 48-well plates $\left(10^{5}\right.$ cells per well). Thereafter the medium was changed and a 72-hour incubation with or without the test substances $(10 \mathrm{nM})$ was performed in quaduplicate. FSH concentrations in the media were determined by an immunoradiometric assay. $* P<0.01$ versus control.

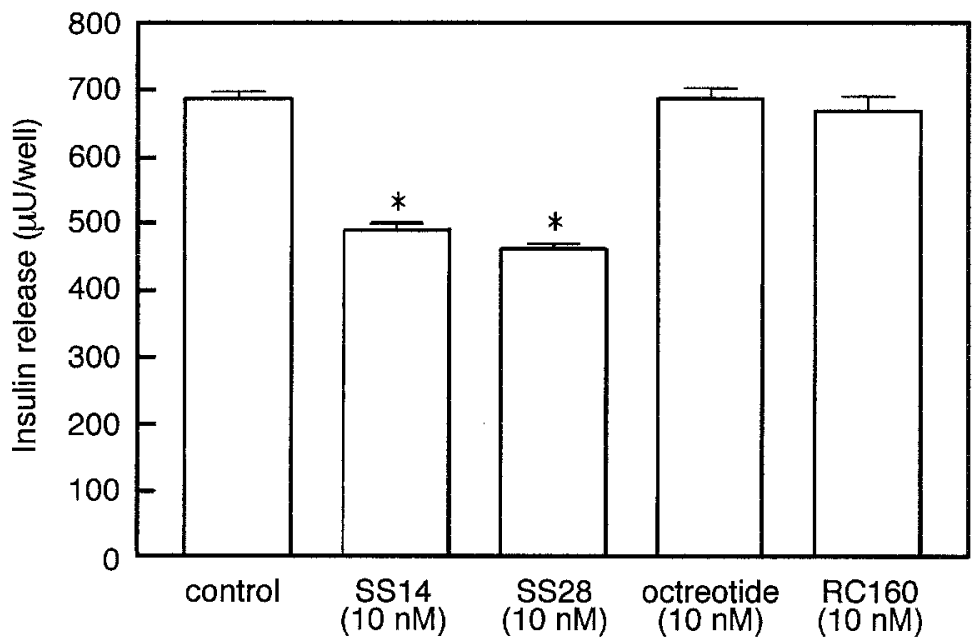

Figure 2. The effects of SS14, SS28 and the SST-analogues octreotide and RC-160 on insulin release by cultured human insulinoma cells. The tumour cells were cultured for 3 days in minimal essential medium with $10 \%$ FCS in 48 -well plates $\left(10^{5}\right.$ cells per well). Thereafter the medium was changed and a 24-hour incubation with or without the test substances $(10 \mathrm{nM})$ was performed in quadruplicate. Insulin concentrations in the media were determined by an immunoradiometric assay. $* P<0.01$ versus control. 
in these cell lines, suggesting that SST(-analogues) may exert anti-tumour effects via SSTR2 subtype receptors. However, it is not clear whether this anti-mitotic action is mediated via a direct or indirect effect (via the inhibition of autocrine and/or paracrine growth factor secretion). Both direct and indirect effects seem possible because the SSTR2 subtype is linked to inhibition of $\mathrm{Ca}^{2+}$-influx and cAMP-formation, as well as to stimulation of phosphotyrosine phosphatase activity. These effects have been proposed to be related to inhibition of secretory processes and growth inhibition, respectively.

\section{SOMATOSTATIN RECEPTOR SCINTIGRAPHY AND RECEPTOR SUBTYPES}

The majority of the human tumours carrying SSTR (see above) can also be visualized in vivo by SSTR scintigraphy using radiolabelled SSTanalogues. Krenning et al (1992) gave a recent overview of the results of SSTR scintigraphy using [ [23I-Tyr $\left.{ }^{3}\right]$ octreotide and [ ${ }^{111} \mathrm{In}-\mathrm{DTPA}-$ D-Phe ${ }^{1}$ ]octreotide in 1000 patients. Apart from tumours, granulomas and autoimmune processes can also be visualized, probably due to local accumulation of the radiolabelled ligand in activated mononuclear leukocytes (Krenning et al, 1993; van Hagen et al, 1994).

As indicated above, the SSTR2 subtype is most abundantly expressed in a variety of human cancers. A good correlation was found between the presence of SSTR2 mRNA and binding of [ $\left.{ }^{125} I-\mathrm{Tyr}^{3}\right]$ octreotide using in situ hybridization and SSTR-autoradiography, respectively (Reubi et al, 1994b). The radioligands that are used in in vivo SSTR-scintigraphy, [123]Tyr ${ }^{3}$ ]octreotide and [ ${ }^{11}$ In-DTPA-D-Phe ${ }^{1}$ octreotide, have binding character-

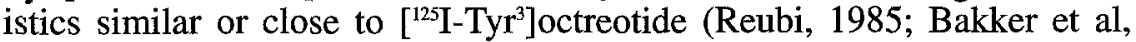
$1990,1991)$. It seems reasonable, therefore, to assume that visualization of SSTR-positive human tumours in vivo is related to visualization of the SSTR2 subtype. However, the SSTR5 subtype also binds the SST-analogue octreotide with high affinity (Table 2). Although in the study by Kubota et al (1994) no SSTR5 mRNA was found in two cases of glucagonoma, in four insulinomas, one carcinoid and in three phaeochromocytomas, clearly more studies of larger series of tumours are needed to exclude SSTR5 mRNA expression in these types of cancer. Different types of pituitary adenomas have been found to express mRNA for different SSTR subtypes, including SSTR5 (Greenman and Melmed, 1994a,b). Because the SSTR2 and SSTR5 subtypes can be expressed simultaneously in the same tumour (i.e. the majority of the human GH-secreting pituitary adenomas express both subtypes), it is not possible to evaluate the relative contribution of the SSTR2 and SSTR5 subtype in the visualization of these tumours in in vivo SSTRscintigraphy. Moreover, the SSTR3 subtype binds octreotide with a relative low affinity and it cannot be excluded that binding of a low amount of radioligand to SSTR3 in vivo also contributes to the visualization of tumours. Since octreotide does not bind to the SSTR1 and SSTR4 subtypes, it can be excluded that these subtypes are visualized by SSTR-scintigraphy in vivo. 
Some subgroups of human tumours have binding sites for native SST, but not for octreotide. These tumours cannot be visualized by in vivo SSTR-scintigraphy (Lamberts et al, 1991; Krenning et al, 1993). Among these subgroups of tumours are certain insulinomas, carcinoids, medullary thyroid carcinomas and ovarian cancers (Reubi et al, 1992a,b). The development of novel DTPA (diethylenetriamine pentaacetic acid) coupled SST-analogues with high affinity towards the SSTR1, SSTR3 and SSTR4 subtypes may provide additional tools for the visualization of these tumours. In terms of SSTR-scintigraphy (not in terms of treatment with SST-analogues), SST-ligands with specificity towards all SSTR subtypes may also be interesting.

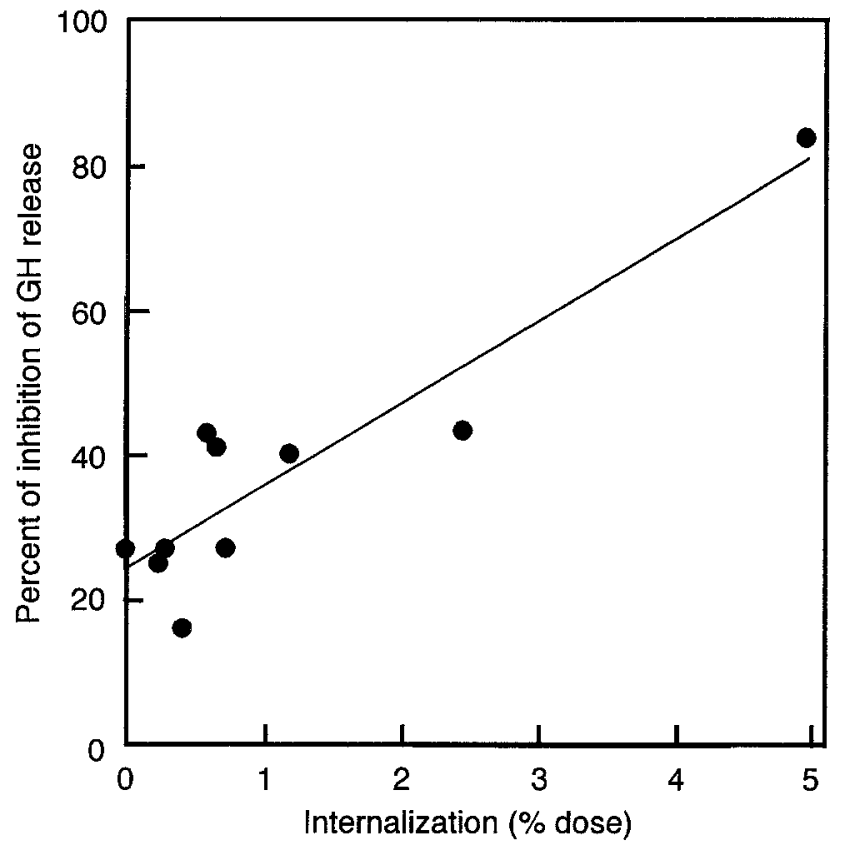

Figure 3. Correlation between the amount of internalization of $\left[{ }^{125} I-T y r^{3}\right]$ octreotide by human GHsecreting pituitary adenoma cells and the percentage of inhibition of $\mathrm{GH}$ release induced by $10 \mathrm{nM}$ octreotide by cultured cells from the same adenomas.

For internalization experiments $10^{6}$ cells per well were incubated for 4 hours in Dulbecco's minimal essential medium $+30 \mathrm{mM}$ HEPES $+0.2 \%$ BSA with $0.1 \mathrm{nM}\left[{ }^{125} \mathrm{I}-\mathrm{Ty} \mathrm{r}^{3}\right]$ octreotide and with or without excess $(1 \mu \mathrm{M})$ unlabelled octreotide to determine non-specific binding. Thereafter, the cells were washed twice with ice-cold medium and surface-bound radioligand was removed by low $\mathrm{pH}$ treatment as described previously (Presky and Schönbrunn, 1988). The amount of remaining radioactivity in the cells represents internalized radioligand.

Cultured human GH-secreting pituitary adenoma cells were incubated for 72 hours in quadruplicate $\left(10^{5}\right.$ cells per well) in minimal essential medium plus $10 \%$ fetal calf serum with or without $10 \mathrm{nM}$ octreotide. GH concentrations in the culture media were determined by an immunoradiometric assay as described previously (Hofland et al, 1989).

$R=0.830 ; P=0.0002$. 
Radiotherapy using SST-analogues coupled to $\alpha$ - or $\beta$-emitting isotopes has been proposed as an application for radiolabelled SST analogues and has recently been carried out in one patient (Krenning et al, 1994). In order to develop this possibility further, it is of importance to know whether radiolabelled SST-analogues are internalized by SSTR-positive tumour cells. Our preliminary results show that the radioiodinated SSTanalogue ${ }^{125}\left[-\mathrm{Tyr}^{3}\right]$ octreotide is internalized in a high amount by SSTRpositive AtT20 pituitary tumour cells and by primary cultures of human GH-secreting pituitary tumour cells. In the GH-adenoma cell cultures a good correlation was found between the inhibition of GH release by octreotide and the amount of internalization of $\left.{ }^{[25}{ }^{12}-\mathrm{Tyr}^{3}\right]$ octreotide (Figure 3 ). Internalization of octreotide may also explain the long residence time of radioactivity on human tumours in vivo in SSTR-scintigraphy (Krenning et al, 1993). Both AtT20 pituitary tumour cells (Patel et al, 1994a) and human GH-adenomas (Greenman and Melmed, 1994a,b; Panetta and Patel, 1995) express multiple SSTR subtypes, including the SSTR2 and SSTR5 subtypes, to which octreotide binds with high affinity. At present it is not clear which SSTR subtype(s) is involved in receptormediated endocytosis.

\section{SUMMARY}

A variety of human neuroendocrine tumours express SSTR. The five recently cloned human SSTR subtypes have a distinct chromosomal localization and pharmacological profile, and a tissue-specific expression pattern which suggests a differential function of SSTR subtypes in different organ systems. Most tumours carrying SSTR may express multiple SSTR subtypes, while the SSTR2 subtype is most predominantly expressed. The somatostatin analogue, octreotide, binds with high affinity to the SSTR2 and SSTR5 subtype and with a low affinity to the SSTR3 subtype. This analogue does not bind to the SSTR1 and SSTR4 subtypes. No major differences in the binding characteristics have been found between octreotide and two other clinically used octapeptide SST-analogues, BIM-23014 and RC-160. Our preliminary data indicate that an absent hormonal response to octreotide in vitro also implies an absent response to BIM23014 and RC-160. The expression of the SSTR2 subtype in human tumours is proposed to be related to a clinical beneficial effect of octreotide treatment, while the functional significance of the other SSTR subtypes is not clear at present. In addition it is unclear which subtype(s) is involved in the antimitotic actions of SST(-analogues). Further developments with regard to the oncological application of SST analogues await the identification of the SSTR subtype(s) mediating anti-proliferative effects, as well as the development of analogues which selectively activate this subtype(s).

A good correlation has been found between the presence of SSTR2 subtype mRNA and binding of [ $\left.{ }^{125} \mathrm{I}-\mathrm{Tyr}^{3}\right]$ octreotide in human primary tumours. Therefore, SSTR scintigraphy of human primary tumours and their metastases presumably visualizes SSTR2-expressing tumours, although it is 
reasonable to assume that SSTR5, and to a lesser extent SSTR3, when expressed simultaneously with SSTR2, also contribute to the visualization of tumours.

\section{REFERENCES}

Akbar M, Okajima F, Tomura $\mathrm{H}$ et al (1994) Phospholipase $\mathrm{C}$ activation and $\mathrm{Ca}^{2+}$ mobilization by cloned human somatostatin receptor subtypes 1-5 in transfected COS-7 cells. FEBS Letters 348: $192-196$.

Bakker WH, Krenning EP, Breeman WA et al (1990) Receptor scintigraphy with a radioiodinated somatostatin analogue: radiolabeling, purification, biological activity, and in vivo application in animals. Journal of Nuclear Medicine 31: 1501-1509.

Bakker WH, Albert R, Bruns C et al (1991) [ ["In-DTPA-D-Phe']octreotide, a potential radiopharmaceutical for imaging of somatostatin-receptor positive tumors: synthesis, radiolabeling and in vitro validation. Life Sciences 49: 1583-1591.

Bauer W, Briner U, Doepfner W et al (1982) SMS 201-995: A very potent and selective octapeptide analogue of somatostatin with prolonged action. Life Sciences 31: 1133-1140.

Besser GM, Mortimer CH, Carr D et al (1974a) Growth hormone release inhibiting hormone in acromegaly. British Medical Journal 1: 352-355.

Besser GM, Mortimer CH, McNeilly AS et al (1974b) Long-term infusion of growth hormone release inhibiting hormone in acromegaly: effects on pituitary and pancreatic hormones. British Medical Journal 4: 622-627.

Brazeau P, Vale W, Burgus R et al (1973) Hypothalamic polypeptide that inhibits the secretion of immunoreactive pituitary growth hormone. Science 179: 77-79.

Bruns C, Weckbecker G, Raulf F et al (1994) Molecular pharmacology of somatostatin-receptor subtypes. Annals of the New York Academy of Sciences 733: 138-146.

Buscail L, Delescque N, Estève J-P et al (1994) Stimulation of tyrosine phosphatase and inhibition of cell proliferation by somatostatin analogues: mediation by human somatostatin receptor subtypes SSTR1 and SSTR2. Proceedings of the National Academy of Sciences of the USA 91: 23152319.

Cai R-Z, Szoke B, Lu R et al (1986) Synthesis and biological activity of highly potent octapeptide analogs of somatostatin. Proceedings of the National Academy of Sciences of the USA 83: 1896-1900.

Cai R-Z, Karashima T, Guoth J et al (1987) Superactive octapeptide somatostatin analogues containing tryptophan at position 1. Proceedings of the National Academy of Sciences of the USA 84: 2502-2506.

Corness JD, Demchyshyn LL, Seeman P et al (1993) A human somatostatin receptor (SSTR3), located on chromosome 22, displays preferential affinity for somatostatin-14 like peptides. FEBS Letters 321: $279-284$.

Demchyshyn LL, Srikant CB, Sunahara RK et al (1993) Cloning and expression of a human somatostatin-14- selective receptor variant (somatostatin receptor 4) located on chromosome 20. Molecular Pharmacology 43: 894-901.

Dodd J \& Kelly J (1978) Is somatostatin an excitatory transmitter in the hippocampus? Nature (London) 273: 674-675.

Eden PA \& Taylor JE (1993) Somatostatin receptor subtype gene expression in human and rodent tumors. Life Sciences 53: 85-90.

Fujii Y, Gonoi T, Yamada Y et al (1994) Somatostatin receptor subtype SSTR2 mediates the inhibition of high-voltage-activated calcium channels by somatostatin and its analogue SMS 201-995. FEBS Letters 355: 117-120.

Fujita T, Yamaji Y, Sato M et al (1994) Gene expression of somatostatin receptor subtypes, SSTR1 and SSTR2, in human lung cancer cell lines. Life Sciences 55: 1797-1806.

Greenman Y \& Melmed S (1994a) Heterogeneous expression of two somatostatin receptor subtypes in pituitary tumors. Journal of Clinical Endocrinology and Metabolism 78: 398-403.

Greenman Y \& Melmed S (1994b) Expression of three somatostatin receptor subtypes in pituitary adenomas: evidence for preferential SSTR5 expression in the mammosomatotroph lineage. Journal of Clinical Endocrinology and Metabolism 79: 724-729. 
Guillemin R (1978) Peptides in the brain: the new endocrinology of the neuron. Science 202: 390-402.

Guillemin R \& Gerich JE (1976) Somatostatin: physiological and clinical significance. Annual Reviews of Medicine 27: 379-388.

Heiman ML, Murphy WA \& Coy DH (1987) Differential binding of somatostatin agonists to somatostatin receptors in brain and adenohypophysis. Neuroendocrinology 45: 429-436.

Hofland LJ, van Koetsveld PM, Verleun TM \& Lamberts SWJ (1989) Glycoprotein hormone alpha subunit and prolactin release by cultured pituitary adenoma cells from acromegalic patients: correlation with GH release. Clinical Endocrinology 30: 601-611.

Hofland LJ, van Koetsveld PM, Waaijers M et al (1994) Relative potencies of the somatostatin analogs octreotide, BIM-23014, and RC-160 on the inhibition of hormone release by cultured human endocrine tumor cells and normal rat anterior pituitary cells. Endocrinology 134: 301-306.

Hoyer D, Lubbert H \& Bruns (1994) Molecular pharmacology of somatostatin receptors. Archives of Pharmacology 350: 441-453.

Janson ET, Westlin J-E, Eriksson B et al (1994) [ ${ }^{111}$ In-DTPA-D-Phe']octreotide scintigraphy in patients with carcinoid tumours: the predictive value for somatostatin analogue treatment. European Journal of Endocrinology 131: 577-581.

Kaupmann K, Bruns C, Hoyer D et al (1993) Distribution and second messenger coupling of four somatostatin receptor subtypes expressed in brain. FEBS Letters 331: 53-59.

Krenning EP, Kwekkeboom DJ, Bakker WH et al (1993) Somatostatin receptor scintigraphy with [ ${ }^{11}$ In-DTPA-D-Phe $]$ - and [ $\left.\left.{ }^{123}\right]-T y r^{3}\right]$-octreotide: the Rotterdam experience with more than 1000 patients. European Journal of Nuclear Medicine 20: 716-731.

Krenning EP, Kooij PPM, Bakker WHB et al (1994) Radiotherapy with a radiolabeled somatostatin analogue, ['"In-DTPA-D-Phe']octreotide: a case history. Annals of the New York Academy of Sciences 733: 496-506.

Kubota A, Yamada Y, Kagimoto S et al (1994) Identification of somatostatin receptor subtypes and an implication for the efficacy of somatostatin analogue SMS 201-995 in treatment of human endocrine tumors. Journal of Clinical Investigation 93: 1321-1325.

Lamberts SWJ (1988) The role of somatostatin in the regulation of anterior pituitary hormone secretion and the use of its analogs in the treatment of human pituitary tumors. Endocrine Reviews 9: 417-436.

Lamberts SWJ, Krenning EP \& Reubi JC (1991) The role of somatostatin and its analogs in the diagnosis and treatment of tumors. Endocrine Reviews 12: 450-482.

Liebow C, Reilly C, Serrano M \& Schally AV (1989) Somatostatin analogues inhibit growth of pancreatic cancer by stimulating tyrosine phosphatase. Proceedings of the National Academy of Sciences of the USA 86: 2003-2007.

Maurer R \& Reubi J-C (1985) Brain somatostatin receptor subpopulation visualized by autoradiography. Brain Research 333: 178-181.

O'Carrol AM, Raynor K, Lolait S \& Reisine T (1994) Characterization of cloned human somatostatin receptor SSTR5. Molecular Pharmacology 46: 291-298.

Panetta R \& Patel YC (1995) Expression of mRNA for all five human somatostatin receptors (hSSTR1-5) in pituitary tumors. Life Sciences 56: 333-342.

Panetta R, Greenwood MT, Warszynska A et al (1994) Molecular cloning, functional characterization, and chromosomal localization of a human somatostatin receptor (somatostatin receptor type 5) with preferential affinity for somatostatin-28. Molecular Pharmacology 45: 417427.

Parmar H, Bogden A, Mollard M et al (1989) Somatostatin and somatostatin analogues in oncology. Cancer Treatment Reviews 16: 95-115.

Patel YC \& Srikant CB (1994) Subtype selectivity of peptide analogs for all five cloned human somatostatin receptors (hsstr 1-5). Endocrinology 135: 2814-2817.

Patel YC, Murthy KK, Escher EE et al (1990) Mechanism of action of somatostatin: an overview of receptor function and studies of the molecular characterization and purification of somatostatin receptor proteins. Metabolism 39: 63-69.

Patel YC, Panetta R, Escher E et al (1994a) Expression of multiple somatostatin receptor genes in AtT-20 cells. Journal of Biological Chemistry 269: 1506-1509.

Patel YC, Greenwood MT, Warszynska A et al (1994b) All five cloned human somatostatin receptors (hSSTR1-5) are functionally coupled to adenylyl cyclase. Biochemical and Biophysical Research Communications 198: 605-612. 
Pradayrol L, Jörnvall H, Mutt V \& Ribet A (1980) N-terminally extended somatostatin: The primary structure of somatostatin-28. FEBS Letters 109: 55-58.

Presky DH \& Schonbrunn A (1988) Somatostatin pretreatment increases the number of somatostatin receptors on $\mathrm{GH}_{4} \mathrm{C}_{1}$ pituitary cells and does not reduce cellular responsiveness to somatostatin. Journal of Biological Chemistry 263: 714-721.

Prévost G, Lanson M, Thomas F et al (1992) Molecular heterogeneity of somatostatin analogue BIM$23014 \mathrm{C}$ receptors in human breast carcinoma cells using the chemical cross-linking assay. Cancer Research 52: 843-850.

Prévost G, Provost P, Sallé V et al (1993) A cross-linking assay allows the detection of receptors for the somatostatin analogue, Lanreotide in human breast tumours. European Journal of Cancer 29: 1589-1592.

Prévost G, Bourgeois Y, Mormont C et al (1994) Characterization of somatostatin receptors and growth inhibition by the somatostatin analogue BIM23014 in small cell lung carcinoma xenograft: SCLC-6, Life Sciences 55: 155-162.

Renaud L, Martin J \& Brazeau P (1975) Depressant action of TRH, LH-RH and somatostatin on activity of central neurones. Nature (London) 255: 233-235.

Rens-Domiano S \& Reisine T (1992) Biochemical and functional properties of somatostatin receptors. Journal of Neurochemistry 58: 1987-1996.

Reubi J-C (1984) Evidence of two somatostatin-14 receptor types in rat brain cortex. Neuroscience Letters 49: 259-263.

Reubi J-C (1985) New specific radioligand for one subpopulation of brain somatostatin receptors. Life Sciences 36: 1829-1836.

Reubi J-C, Probst A, Cortes R \& Palacios JM (1987) Distinct topographical localization of two somatostatin receptor subpopulations in the human cortex. Brain Research 406: 391-396.

Reubi J-C, Krenning E, Lamberts SWJ \& Kvols L (1992a) In vitro detection of somatostatin receptors in human tumors. Metabolism 41: 104-110.

Reubi J-C, Laissue J, Krenning E \& Lamberts SWJ (1992b) Somatostatin receptors in human cancer: incidence, characteristics, functional correlates and clinical implications. Journal of Steroid Biochemistry and Molecular Biology 43: 27-35.

Reubi J-C, Horisberger U \& Laissue J (1994a) High density of somatostatin receptors in veins surrounding human cancer tissue: role in tumor-host interaction. International Journal of Cancer 56: $681-688$.

Reubi JC, Schaer JC, Waser B \& Mengod G (1994b) Expression and localization of somatostatin receptor SSTR1, SSTR2, and SSTR3 messenger RNAs in primary human tumors using in situ hybridization. Cancer Research 54: 3455-3459.

Rohrer L, Raulf F, Bruns C et al (1993) Cloning and characterization of a fourth human somatostatin receptor. Proceedings of the National Academy of Sciences of the USA 90: 41964200 .

Schally AV (1988) Oncological applications of somatostatin analogues. Cancer Research 48: $6977-6985$.

Taylor JE, Theveniau MA, Bashirzadeh R et al (1994) Detection of somatostatin receptor subtype 2 (SSTR2) in established tumors and tumor cell lines: evidence for SSTR2 heterogeneity. Peptides 15: $1229-1236$.

Tomura H, Okajima F, Akbar M et al (1994) Transfected human somatostatin receptor type 2, SSTR2, not only inhibits adenylate cyclase but also stimulates phospholipase $\mathrm{C}$ and $\mathrm{Ca}^{2+}$ mobilization. Biochemical and Biophysical Research Communications 200: 986-992.

Tran V, Beal MF \& Martin JB (1985) Two types of somatostatin receptors differentiated by cyclic somatostatin analogs. Science 228: 492-495.

van Hagen PM, Krenning EP, Kwekkeboom DJ et al (1994) Somatostatin and the immune and haematopoetic system; a review. European Journal of Clinical Investigation 24: 91-99.

Xu Y, Song J, Bruno JF \& Berelowitz M (1993) Molecular cloning and sequencing of a human somatostatin receptor, hSSTR4. Biochemical and Biophysical Research Communications 193: 648-652.

Yamada Y, Post SR, Wang K et al (1992a) Cloning and functional characterization of a family of human and mouse somatostatin receptors expressed in brain, gastro-intestinal tract and kidney. Proceedings of the National Academy of Sciences of the USA 89: 251-255.

Yamada Y, Reisine T, Law SF et al (1992b) Somatostatin receptors, an expanding gene family: cloning and functional characterization of human SSTR3, a protein coupled to adenylyl cyclase. Molecular Endocrinology 6: 2136-2142. 
Yamada Y, Kagimoto S, Kubota A et al (1993a) Cloning, functional expression and pharmacological characterization of a fourth (hSSTR4) and a fifth (hSSTR5) human somatostatin receptor subtype. Biochemical and Biophysical Research Communications 195: 844-852.

Yamada Y, Stoffel M, Espinosa III R et al (1993b) Human somatostatin receptor genes: localization to human chromosomes 14,17 , and 22 and identification of simple tandem repeat polymorphisms. Genomics 15: 449-452. 